\title{
SOCIAL AND CULTURAL FACTORS AND THEIR IMPACT ON THE QUALITY OF BUSINESS ENVIRONMENT IN THE SME SEGMENT
}

\author{
Martin Čepel \\ Pan-European University in Bratislava \\ Bratislava, Slovak Republic \\ martin.cepel@paneurouni.com
}

\begin{abstract}
A stable, prosperous and competitive economic system in every developed country requires a high-quality business environment in the SME sector. The quality of the business environment is a key factor in the economic development of countries, as it is of a great importance for the growth of the economy's competitiveness and also for its future and sustainable economic growth. The aim of the article was to quantify the significant social and cultural factors creating the quality of the business environment in the SME segment and to compare their importance in the Czech and Slovak Republic. Within the context of the stated aim of the research, questionnaire survey was carried out among the enterprises operating in the SME segment. Within the research, 312 companies in the CR and 320 companies in Slovakia were addressed. The Z-score method was used to verify the established scientific hypotheses. The research has brought up some interesting results. The research results point to a significant finding that the entrepreneurs in both countries have experienced a relatively low public and political acceptance. On the other hand, the entrepreneurs stated that the family environment motivates them to do business and helps them with their entrepreneurial activities. The assessing of the media impact on the business is quite negative in both countries. Entrepreneurs have largely thought that the media misrepresent doing business in general and do not help to shape the business environment, e.g. through the presentation of business success stories. More than the two-thirds of entrepreneurs in both countries have agreed that the doing business' advantages outweigh the disadvantages. This research has some limitations, but is has brought interesting findings and a potential inspiration for further research to explore the issue of the quality of the business environment of SMEs.
\end{abstract}

KEYWORDS: business environment, cultural factors, quality of business environment, social climate, social factors

JEL CLASSIFICATION: L26

DOI: 10.2478/IJEK-2019-0005

Received: April 14 $4^{\text {th }}, 2019$.

1st Revision: April $30^{\text {th }} 2019$.

Accepted: May $15^{\text {th }} 2019$

Reference: Čepel, M. (2019). Social and Cultural Factors and Their Impact On The Quality Of Business Environment In the SME Segment. International Journal of Entrepreneurial Knowledge, 7(1), 65-73. doi: 10.2478/ijek-2019-0005

\section{INTRODUCTION}

A stable, prosperous and competitive economic system in every developed country requires a high quality business environment in the SME sector.(Dobeš et al., 2017; Kozubíková et al., 2017; Ključnikov and Popesko, 2017; Belas et al., 2015).

Small and medium-sized enterprises - enterprises up to 250 employees and annual turnover of 50 mil. EUR, make up the most numerous type of enterprises in Europe, as shown by statistics - 99\% of businesses in Europe are SMEs, while SMEs employ almost $75 \%$ of all people working in the private sector. For this reason, not only Slovakia but also the EU as a whole has a strong interest in creating favorable conditions for their functioning and development (Slovak Business Agency, 2018). 
The quality of the business environment determines significantly the decision of individuals to start their own entrepreneurial activities while creating the basic conditions for the development of small and medium-sized enterprises.

The quality of the business environment is often regarded as a major factor in the long-term economic competitiveness and sustainable development of small and medium-sized enterprises.According to the OECD, factors influencing the business environment can be divided into 4 main areas: institutional and regulatory framework, market access, access to resources and business culture(Slovak Business Agency, 2018).

This article examines the significant social and cultural factors in the business environment and quantifies their significance in the Czech Republic and Slovakia, and compares their intensity in both countries.

The structure of the article is as follows. The theoretical part presents the results of research in the field of social and cultural factors of business environment. The next section defines the research goal, methodology and data. The third part presents the results of the research and a short discussion on the given issue. In the final part of the article, the basic conclusions of the research are formulated.

\section{THEORETICAL PART}

The quality of the business environment is a key factor in countries' economic growth, as it plays an important role in the economy's competitiveness growth and future economic sustainability (Wruuck, 2015, Bunoa et al., 2015, Chládková, 2015). In this context, it is extremely important to shape a good business environment for the SME segment.

According to Bunoa et al. (2015), the business environment within an enterprise comprises economic, political, institutional, legal, technological, and cultural conditions that enable and shape the enterprises' business activities. Similar conclusions are also given by Conorto et al. (2014), who highlight the importance of social and cultural factors in creating a high quality business environment in the SME segment.

The Entrepreneurship 2020 Action Plan (European Commission, 2013) states: "Potential entrepreneurs in Europe generally do not have a business-friendly environment. education does not provide the right basis to start a business career, difficult access to credit and markets, difficulties in transferring businesses, concerns about criminal penaltiesand burdensome administrative procedures.In addition, support measures for SMEs remain unbalanced, as a large number of EU Member States still do not take into account the characteristics of small businesses, especially micro-enterprises, when preparing legislation, nor do they offer a second chance to honest bankrupt entrepreneurs. Not only is this environment problematic, but there also dominates a culture that does not recognize or reward entrepreneurial efforts enough and does not refer to successful entrepreneurs as patterns that create jobs and income. Europe must go through a thorough and extensive cultural change to drive entrepreneurship to grow our economy."

Entrepreneurship can be seen as a factor affecting the social and cultural environment and as a factor that can be influenced by them (Powell \& Rodet, 2012). Entrepreneurship leads to social, technological and economic development and growth. Individuals involved in entrepreneurial activities are those who operate on them in different ways. In this context, Zahra and Wright (2016) argued that, given the growing recognition of the role of entrepreneurship, its possible social impact is also apparent.

Scholars have paid attention to the social values that entrepreneurship adds to society. Zahra and Wright (2016) have developed five pillars that could affect the social role of entrepreneurship. The first 
pillar was to link entrepreneurship with other societal endeavors that point to the achievement of a better standard of living, advancement in development and enrichment of one's existence.

Secondly, exploring ways to reduce the dysfunctional impact of entepreneurship on stakeholders. The third pillar is related to the need for a new definition of the entrepreneurship scope as a scientific arena. The fourth pillar is the need to know the social multiplier of entrepreneurship. Finally, the fifth pillar points to the company level that is concerned with balancing the creation of environmental, social and financial wealth.

As mentioned earlier, entrepreneurial activity can be influenced by social and cultural environment in which it operates. Schumpeter (1934) claimed that entrepreneurship is influenced by profits and social climate, that is, the economy, sociological and institutional dimensions of a society. It consists of a social dimension known as the social environment in which individuals engage in entrepreneurial activity and its progress. As a result, it also includes social values among other things.In the view of this, it is essential that the person involved in the entrepreneurial activity is familiar with and admits the rules of the game, ie the environmental circumstances. Schumpeter (1934) argued that the distribution in terms of income in a society represents the social climate.Social stress would be present in an unequal society, unions would force the government to introduce other forms of taxation distribution, and would not positively affect entrepreneurs to increase their activities. Cultural aspects are also covered by the concept of social climate.

Scholars have examined the social and cultural factors in their analyses concerning their role on entrepreneurship(Castaño, Méndez, \& Galindo, 2015; Curado, Henriques, \& Bontis, 2011; C. Huang \& Kung, 2011; Y. Huang \& Jim Wu, 2010; Naranjo-Valencia, Jiménez-Jiménez, \& Sanz-Valle, 2011). To do that, Nissan, Galindo and Picazo(2012) suggest to include culture in the Schumpeterian social climate. Consequently, in a society, through culture, models of behaviour and conductenabling the associations among people are introduced. Because of the culture factor that could be perceived as a way of doing business in a particular society, the intentions of individuals to innovate could differ. (Y. Huang \& Jim Wu, 2010; Rowley, Baregheh, \& Sambrook, 2011). Institutions stimulating a business culture among households, businesses and the government support entrepreneurial activity. Innovation is an important driver that may lead to these results (Nissan et al., 2012).

Powell and Rodet (2012) and Castaño et al. (2015) found empirical evidence emphasizing the impact of the cultural environment on entrepreneurial activity. The social and cultural environment would thus influence economic development through entrepreneurship and innovation. Culture and the social environment can motivate individuals to engage inentrepreneurial activity.

\section{THE AIM, METHODOLOGY AND DATA}

The aim of the article was to quantify the important social and cultural factors creating the quality of the business environment in the SME segment and to compare their importance in the Czech Republic and Slovakia.

In regards to the defined aim, a survey-based research was conducted with enterprises operating in the SME segment. 312 enterprises in CR and 329 enterprises in SR were approached during this research. Data collection took place in 2018. The method of random choice using the "Randbetween" mathematical function was used to select enterprises from the "Albertína" database comprising enterprises in the Czech Republic. Slovak enterprises were randomly selected from the "Cribis" database containing the list of enterprises, organizations, and entrepreneurs. The enterprises were approached via email asking them to fill out the online questionnaire. The questionnaire was intended for business owners or top management (hereinafter entrepreneurs). The response rate in the Czech Republic was approximately $4 \%$ (out of over 7800 enterprises). The number of approached enterprises 
in the Slovak Republic was more than 9400, and the response rate was approximately $3.5 \%$. The structure of respondents within the Czech Republic (312 enterprises) was the following: business area: services 109 enterprises, retail 73 enterprises, manufacturing 53 enterprises, construction 29 enterprises, agriculture 9 enterprises, transportation 19 enterprises, other business area 23 enterprises. Time period of operating a business: 56 enterprises $1-5$ years, 48 enterprises $5-10$ years, 208 enterprises more than 10 years. Size of business: 258 micro-enterprises (up to 10 employees), 43 small enterprises (up to 50 employees), and 11 medium-sized enterprises (up to 250 employees). Highest attained education level of the entrepreneur: 50 high school without diploma, 135 high school with diploma, and 127 college education. Gender of entrepreneurs: 236 men, 76 women.

The structure of respondents within the Slovak Republic (329 enterprises) was following: business area: services 122 enterprises, retail 69 enterprises, manufacturing 51 enterprises, construction 39 enterprises, agriculture 20 enterprises, transportation 11 enterprises, other business area 17 enterprises. Time period of operating a business: 104 enterprises $1-5$ years, 78 enterprises $5-10$ years, and 147 enterprises more than 10 years. Size of business: 234 micro-enterprises (up to 10 employees), 71 small enterprises (up to 50 employees), and 24 medium-sized enterprises (up to 250 employees). Highest attained education level of the entrepreneur: 10 high school without diploma, 95 high school with diploma, and 224 college education. Gender of entrepreneurs: 251 men, 78 women.

Within the research, four groups of social and cultural factors were defined through the following statements:

Social factors $(\mathrm{SF})$

SF1: Entrepreneurs' views and evaluation of the social environment

SF11: Our society appreciates entrepreneurs.

SF12: Politicians and the public correctly understand how entrepreneurs contribute to the society.

SF13: My close environment (family, friends, acquaintances) help me in doing business.

SF14: Good business practices help shape the quality of business environment.

SF2: Family environment

SF21: The family environment motivates people to start a business.

SF22: It is easier to do business if close relatives are in business.

SF23: I acquired many skills in my family that help me in my business.

SF24: My family helps me in my business.

SF3: Media and communication environment

SF31: Media (television, broadcast, and other media) truthfully inform about entrepreneurship.

SF32: Media help shape the quality of business environment using presentations of goof business practices.

SF33: Media adequately inform about the business environment.

SF34: Media support entrepreneurs' communication with the public.

SF4: Entrepreneurs' social stance

SF41: The advantages of doing business outnumber the disadvantages.

SF42: An entrepreneur is wealthier and has a higher social status.

SF43: Entrepreneurship enables a better career growth and leads to interesting work opportunities.

SF44: Conducting business allows for a full utilization of one's skills. 


\section{In developing this paper we have established four scientific hypotheses:}

H1: There are statistically significant differences in the evaluation of the social environment (SF1) by Czech and Slovak enterprises.

H2: There are statistically significant differences in the evaluation of the family environment(SF2) by Czech and Slovak enterprises.

H3: There are statistically significant differences in the evaluation media environment(SF3) by Czech and Slovak enterprises.

H4: There are statistically significant differences in the evaluation of social attitudes (SF4) by Czech and Slovak enterprises.

To evaluate H1, H2, H3 and H4, the method of Z score was used. Statistically significant differences between the positive answers of Czech and Slovak respondents were compared through Pearson statistics at the significance level of $5 \%$. If the calculated p-value was lower than $5 \%$, the null hypothesis was rejected, and the alternative hypothesis was adopted. The calculations were made through the free software available athttp://www.socscistatistics.com/tests/ztest/Default2.aspx.

\section{RESULTS AND DISCUSSION}

The research results are listed in the tables below.

Table 1 - Evaluation of social factors (SF1) in CR and SR

\begin{tabular}{|l|c|r|}
\hline Factor & $\begin{array}{c}\text { The proportion of positive } \\
\text { responses } \\
\text { (CR/SR index) }\end{array}$ & $\begin{array}{l}\text { Z-score } \\
\text { p-value }\end{array}$ \\
\hline SF11 & $0.199 / 0.280$ & $\mathbf{0 . 0 0 3}$ \\
\hline SF12 & $0.090 / 0.155$ & $<\mathbf{0 . 0 0 1}$ \\
\hline SF13 & $0.827 / 0.821$ & 0.833 \\
\hline SF14 & $0.503 / 0.657$ & $<\mathbf{0 . 0 0 1}$ \\
\hline
\end{tabular}

(Source:own processing)

$19.9 \%$ of respondents in the Czech Republic and $28 \%$ of respondents in Slovakia agreed with the statement that the society appreciates entrepreneurs (SF11).

Only $9 \%$ of Czech and $15.5 \%$ of Slovak entrepreneurs agree that politicians and the public correctly understand the contribution of entrepreneurs to society (SF12).

$26 \%$ of respondents in the Czech Republic and 28\% of respondents in the Slovak Republic agreed that My close environment (family, friends, acquaintances) support me in business (SF13).

$50.4 \%$ of entrepreneurs in the Czech Republic and $65.7 \%$ of entrepreneurs in the Slovak Republic agreed that SF14: Good business practives help shape the quality of the business environment (SF14). 
The results of the testing criterion p-value $(0.003 ;<0.001 ; 0.833 ;<0.001)$ confirm that there are statistically significant differences between respondents' answers in the two countries.Slovak entrepreneurs are more positive about the support from society, politicians and the public compared to the Czech entrepreneurs. At the same time, Slovak entrepreneurs have more intensely agreed that good business practices help shape the quality of the business environment.

H1 was confirmed.

Table 2 - Evaluation of social factors (SF2) in CR and SR

\begin{tabular}{|l|r|r|}
\hline Factor & $\begin{array}{c}\text { The proportion of positive } \\
\text { responses } \\
\text { (CR/SR index })\end{array}$ & $\begin{array}{c}\text { Z-score } \\
\text { p-value }\end{array}$ \\
\hline SF21 & $0.545 / 0.620$ & $<\mathbf{0 . 0 0 1}$ \\
\hline SF22 & $0.657 / 0.729$ & $\mathbf{0 . 0 4 7}$ \\
\hline SF23 & $0.542 / 0.687$ & $<\mathbf{0 . 0 0 1}$ \\
\hline SF24 & $0.817 / 0.796$ & 0.503 \\
\hline
\end{tabular}

(Source:own processing)

The results in the Table 2 highlight the importance of a family environment for entrepreneurs. 54.5\% of Czech entrepreneurs and $62 \%$ of Slovak entrepreneurs said that the family environment motivated them to do business. The majority of entrepreneurs have said that it is easier to do business if one of the close relatives does business.More than half of entrepreneurs have confirmed that they have gained a lot of knowledge in the family that helps them in business. Around $80 \%$ of respondents in both countries said the family was helping them in business.

The results of the testing criterion $\mathrm{p}$-value $(<0.001 ; 0,047 ;<0.001 ; 0.503)$ confirm that there are statistically significant differences between respondents' answers in the two countries. Slovak entrepreneurs perceive positively the role of a family environment in business (statistically significant differences in respondents' positive responses were recorded for SF21, SF22 and SF23).

H2 was confirmed.

Table 3 - Evaluation of social factors (SF3) in CR and SR

\begin{tabular}{|l|r|r|}
\hline Factor & $\begin{array}{c}\text { The proportion of positive } \\
\text { responses } \\
\text { (CR/SR index })\end{array}$ & $\begin{array}{l}\text { Z-score } \\
\text { p-value }\end{array}$ \\
\hline SF31 & $0.170 / 0.252$ & $\mathbf{0 . 0 1 1}$ \\
\hline SF32 & $0.199 / 0.331$ & $<\mathbf{0 . 0 0 1}$ \\
\hline SF33 & $0.276 / 0.337$ & 0.091 \\
\hline SF34 & $0.208 / 0.392$ & $<\mathbf{0 . 0 0 1}$ \\
\hline
\end{tabular}

(Source:own processing)

Assessing the media impact on entrepreneurship is rather negative. Only $17 \%$ of entrepreneurs in the Czech Republic and 25.2\% of entrepreneurs in Slovakia have confirmed the opinion that Media (television, radio and other media) truthfully inform about entrepreneurship (SF31).Only 19.9\% of Czech entrepreneurs and 33.1\% of Slovak entrepreneurs (SF32) agreed that Media help shape the quality of the business environment through the presentation of good business practices (SF32). 
A relatively small proportion of entrepreneurs in both countries agreed with factor SF33: The media informabout the business environment to an appropriate extent. 20.8\% of Czech entrepreneurs and $39.2 \%$ of Slovak entrepreneurs agreed with the view that the media support the communication of entrepreneurs with the public (SF34).

The results of the testing criterion p-value $(0.011 ;<0.001 ;<0.001)$ confirm that there are statistically significant differences between respondents' answers in the two countries.Slovak entrepreneurs perceive the influence of the media environment on the quality of business environment more positively compared to the Czech entrepreneurs (statistically significant differences in the respondents' positive answers were recorded for SF31, SF32 and SF34).

H3 was confirmed.

Table 4 - Evaluation of social factors (SF4) in CR and SR

\begin{tabular}{|l|r|r|}
\hline \multicolumn{1}{|c|}{ Factor } & $\begin{array}{c}\text { The proportion of positive } \\
\text { responses } \\
\text { (CR/SR index) }\end{array}$ & $\begin{array}{l}\text { Z-score } \\
\text { p-value }\end{array}$ \\
\hline SF41 & $0.660 / 0.650$ & 0.795 \\
\hline SF42 & $0.827 / 0.821$ & 0.834 \\
\hline SF43 & $0.631 / 0.669$ & 0.322 \\
\hline SF44 & $0.808 / 0.827$ & 0.535 \\
\hline
\end{tabular}

(Source:own processing)

A relatively large proportion of entrepreneurs in this research responded positively to the various factors in the social attitudes of entrepreneurs. More than $2 / 3$ of entrepreneurs in both countries agreed to claim that the benefits of doing business outweigh the disadvantages (SF41).

The highest level of consent was found in the SF42: Entrepreneur has more money and better social status (up to $82.7 \%$ of Czech entrepreneurs and $82.1 \%$ of Slovak entrepreneurs agreed with this statement.

The results of the testing criterion p-value $(0.795 ; 0.834 ; 0.322 ; 0.535)$ confirm that there are not statistically significant differences between respondents' answers in the two countries.

H4 was not confirmed.

Research results have yielded some interesting results. Entrepreneurs in both countries felt a relatively low level of acceptance by the society and presented the view that the media misunderstood the contribution of entrepreneurs to society.

An important problem is the perception of entrepreneurs by society. E.g. According to the GfK Czech survey (2015), only 55\% of the total number of respondents positively perceived entrepreneurs. At the same time, respondents said entrepreneurs respect their customers less than in the past. In this context, the media play an important role in shaping society's attitudes towards the business environment.

Similarly, Belás et al. (2015) report that the perception of entrepreneurs in the society is not optimal. People who do not do business, consider entrepreneurs rather negatively also because the media give a priority to the negative business news. Research by these authors has shown that up to $71 \%$ of 
entrepreneurs in the SME segment thought that the media was insufficiently informed about the importance of entrepreneurs for the whole of society.

On the other hand, entrepreneurs have declared great importance to the family environment for their business activities. The family environment motivates them to do business and helps them in business.

The results of the research largely confirm the views of the European Commission. In the document entitled The Entrepreneurship 2020 Action Plan it is stated: "There are only a few stories about entrepreneurial success in Europe. This is because doing business was not the preferred career. In Europe, we rarely find an entrepreneur profession among the most sought-after professions. Although entrepreneurs create jobs and stimulate the economy, their successes are not presented as a model in the media. For young people, entrepreneur's career is a low-profile one, discouraging those who want to become entrepreneurs. An important element in the change of business culture is therefore a change in the perception of entrepreneurs on the basis of practical and positive information about their achievements, benefits for society and the possibility of establishing new businesses or acquisitions as a career goal. In order to achieve this, it is necessary to speed up their visibility as role models, taking into account the diversity of business profiles and ways to achieve a success. Clear and engaging information about the challenges and rewards of a business career can undermine negative impressions. Therefore, a broader public debate, especially in the media, is needed for the business revolution. Public and private institutions should be encouraged to emphasize the social and economic importance of entrepreneurs not only as a generally recognized career, but also as a matter of extraordinary national, European and international interest"(European Commission, 2013).

\section{CONCLUSION}

The aim of the article was to quantify the important social and cultural factors creating the quality of the business environment in the SME segment and to compare their importance in the Czech Republic and Slovakia.

The research results point to a significant finding that the entrepreneurs in both countries have experienced a relatively low public and political acceptance. On the other hand, the entrepreneurs stated that the family environment motivates them to do business and helps them with their entrepreneurial activities

The assessing of the media impact on the business is quite negative in both countries. Entrepreneurs have largely thought that the media misrepresent doing business in general and do not help to shape the business environment, e.g. through the presentation of business success stories. More than the twothirds of entrepreneurs in both countries have agreed that the doing business' advantages outweigh the disadvantages.

This research has some limitations, but is has brought interesting findings and a potential inspiration for further research to explore the issue of the quality of the business environment of SMEs.

In further research, we plan to explore the importance of political, technological and economic factors affecting the quality of the business environment.

\section{REFERENCES}

Belas, J., Kljucnikov, A., Vojtovic, S., \& Sobekova-Májkova, M. (2015). Approach of the SME Entrepreneurs to Financial Risk Management in Relation to Gender and Level of Education. Economics and Sociology, Vol. 8, No 4, pp. 32-42. 
Belás, J., Bartoš, P., Ključnikov, A., \& Kozubíková, L. (2015). Významné determinanty kvality podnikatel'ského prostredia MSP. Scientific papers of the University of Pardubice Series D, Vol. XXII, No. 35, pp. 5-17.

Bunoa, M., Nadanyiova, M., Hraskova, D. (2015). The comparison of the quality of business environment in the countries of Visegrad group. Procedia Economics and Finance 26: 423-430.

Castaño, M.-S., Méndez, M.-T., \& Galindo, M.-Á. (2015). The effect of social, cultural, and economic factors on entrepreneurship. Journal of Business Research, 68(7), 1496-1500. https://doi.org/10.1016/i.jbusres.2015.01.040

Conorto, R. a kol. (2014). Analýza, monitor kvality podnikatel'ského prostredia v SR a konkurencie schopnost' ekonomiky. Bratislava: Centrum vzdelávania MPSVR SR.

Curado, C., Henriques, L., \& Bontis, N. (2011). Intellectual capital disclosure payback. Management Decision, 49(7), 1080-1098. https://doi.org/10.1108/00251741111151154

Dobeš, K., Kot, S., Kramoliš, J., \& Sopková, G. (2017).The Perception of Governmental Support in The Context of Competitiveness of SMEs in the Czech Republic. Journal of Competitiveness, Vol. 9 , Issue 3, pp. 34-50. DOI: 10.7441/joc.2017.03.03

Európska komisia. (2013). Akíný plán pre podnikanie 2020. Oznámenie komisie Európskemu parlamentu, Rade, Európskemu hospodárskemu a sociálnemu výboru a Výboru regiónov. Brusel: EK.

GfK Czech. (2013).Prĩzkum: Podnikatelé jsou vnimani pozitivnèji. Praha: ČTK. Available at: http://www.podnikatel.cz/clanky/pruzkum-podnikatele-jsou-vnimani- pozitivneji/

Huang, C., \& Kung, F. (2011). Environmental consciousness and intellectual capital management. Management Decision, 49(9), 1405-1425. https://doi.org/10.1108/00251741111173916

Huang, Y., \& Jim Wu, Y. (2010). Intellectual capital and knowledge productivity: the Taiwan biotech industry. Management Decision, 48(4), 580-599. https://doi.org/10.1108/00251741011041364

Chládková, H. (2015). Selected approaches to the business environment evaluation. Acta Universitatis Agriculturae et Silviculturae Mendelianae Brunensis, Volume 63, Number 2, pp. 513-523. http://dx.doi.org/10.11118/actaun201563020515

Ključnikov, A., Popesko, B. (2017). Export and its Financing in The SME Segment. Case Study From Slovakia. Journal of Competitiveness, Vol. 9, Issue 1, pp. 20-35. DOI: 10.7441/joc.2017.01.02

Kozubíková, L., Homolka, L., Kristalas, D. (2017).The Effect of Business Environment and Entrepreneurs' Gender on Perception of Financial Risk in The Smes Sector. Journal of Competitiveness, Vol. 9, Issue 1, pp. 36-50. DOI: 10.7441/joc.2017.01.03

Naranjo-Valencia, J. C., Jiménez-Jiménez, D., \& Sanz-Valle, R. (2011). Innovation or imitation? The role of organizational culture. Management Decision, 49(1), 55-72. https://doi.org/10.1108/00251741111094437

Nissan, E., Galindo, M.-A., \& Picazo, M. T. M. (2012). Innovation, progress, entrepreneurship and cultural aspects. International Entrepreneurship and Management Journal, 8(4), 411-420. https://doi.org/10.1007/s11365-012-0229-0

Powell, B., \& Rodet, C. (2012). Praise and profits: Cultural and institutional determinants of entrepreneurship. Journal of Private Enterprise, 27(2), 19-42.

Rowley, J., Baregheh, A., \& Sambrook, S. (2011). Towards an innovation-type mapping tool. Management Decision, 49(1), 73-86. https://doi.org/10.1108/00251741111094446

Schumpeter, J. A. (1934). The Theory of Economic Development.

Slovak Business Agency (2018). Politikea śtátnej podpory MSP. Available at: http://www.sbagency.sk/politika-statnej-podpory-msp

Wruuck, P. (2015). The business environment in the eurozone. Deutsche Bank AG Deutsche Bank Research Frankfurt am Main Germany. Available at: https://www.dbresearch.com/PROD/DBR INTERNET EN-PROD/ PROD $000000 \quad 00$ 00379559/The business environment in the eurozone $\% 3 \mathrm{~A}$ Why it i.pdf

Zahra, S. A., \& Wright, M. (2016). Understanding the Social Role of Entrepreneurship. Journal of Management Studies, 53(4), 610-629. https://doi.org/10.1111/joms.12149

$\mathrm{Z}$ Score Calculator for 2 Population Proportions. Available at: http://www.socscistatistics.com/tests/ztest/Default2.aspx. 